\title{
The use of YouTube by the Spanish press: A model to be defined
}

\author{
Marina Santín; José-María Álvarez-Monzoncillo
}

Nota: Este artículo se puede leer en español en:

http://www.elprofesionaldelainformacion.com/contenidos/2020/ene/santin-alvarez_es.pdf

How to quote this article:

Santín, Marina; Álvarez-Monzoncillo, José-María (2020). “The use of YouTube by the Spanish press: A model to be defined". El profesional de la información, v. 29, n. 1, e290116.

https://doi.org/10.3145/epi.2020.ene.16

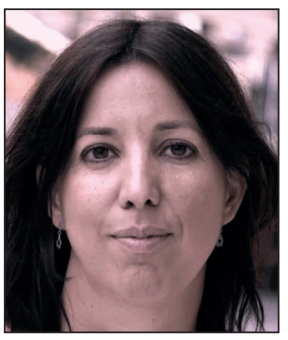

Marina Santín $\square$

https://orcid.org/0000-0002-0036-0861

Universidad Rey Juan Carlos

Facultad de Ciencias de la Comunicación

Campus de Fuenlabrada

Camino del Molino, $\mathrm{s} / \mathrm{n}$.

28943 Fuenlabrada (Madrid), Spain

marina.santin@urjc.es

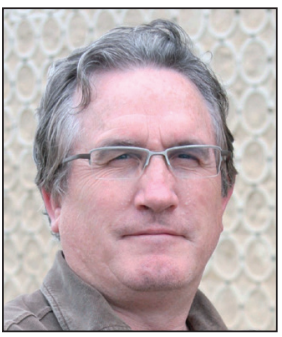

José-María Álvarez-Monzoncillo

https://orcid.org/0000-0002-2009-7466

Universidad Rey Juan Carlos

Facultad de Ciencias de la Comunicación

Campus de Fuenlabrada

Camino del Molino, $s / n$.

28943 Fuenlabrada (Madrid), Spain

josemaria.alvarez@urjc.es

\begin{abstract}
The instability in the newspaper business model since the emergence of the Internet disrupted the value chain and has led newspapers to turn to videos as an additional source of revenue. YouTube has become the content distribution channel of choice for most newspapers, which benefit from the ability to generate greater traffic in exchange for a blind contract imposed by YouTube's algorithm. Advertising income from this source is still scarce and depends on engagement, previous user experience, video quality, video reputation and numerous other factors. Based on an analysis of 864 videos over three randomly selected weeks, conclusions are reached, and the consequences of the management of the YouTube channels of six Spanish newspapers are discussed.
\end{abstract}

\section{Keywords}

YouTube; Business models; Digital journalism; Digital press; Media; Press; Newspapers; Newspaper companies; Newspaper innovation; Engagement; Multimedia; Audiovisual; Online video; Social media; Youtubers; Spain.

\section{Introduction}

The transformation of the journalism industry's business model has forced newspapers to redefine their strategies regarding the creation, distribution, marketing and promotion of content. Faced with this need to restructure, newspapers have chosen, among other approaches, to seek new sources of revenue through the audiovisual value chain. Given the widespread mobility of information consumption

'as part of a pattern of convergence that has generated the broad uptake and use of social media' (Sheridan; Matthews, 2017, p. 1575),

newspapers have established a presence in this area. In this new and incomplete digital ecosystem,

'Spanish media managers consider that Twitter, YouTube and Facebook are the networks that have had the greatest impact on their activities and business' (Campos-Freire et al., 2016, p. 453).

Financing

This article presents research results of the project Análisis del fenómeno youtubers en España: una exploración para identificar los vectores de cambio del mercado audiovisual, financed by the Spanish Ministerio de Economía y Competitividad (code: CSO2016-74977-R). 
Newspaper companies focus their strategies on these social networks as a way of adapting to the new media model, enabling them to exploit the opportunities of the market of convergence.

Accordingly, newspapers disseminate their content beyond their websites, taking a lead role as producers of news on social networks, where the younger members of the audience primarily choose to seek information (Casero-Ripollés, 2012; Gottfried; Barthel, 2015; Santín; Álvarez-Monzoncillo, 2017). In addition, newspapers have opted for a wide variety of content, often adapted to a transmedia interactive format in which the roles of readers (the users) and videos (the format) have taken on a level of importance in the digital press that was unthinkable just a few years ago. Text and photography now stand alongside video, and search engines and social networks have become content prescribers.

This trend reflects younger generations' preference for audiovisual language over written language because of its greater simplicity and appeal. As a result, newspaper publishers have devised strategies to attract this younger audience and thereby boost their revenues. Digital migration also entails a reduction of attention time

'that affects advertising and classic mass media models' (Álvarez-Monzoncillo, 2011, p. 59).

In the battle for this market of attention (Webster, 2014), the media strive to be providers not only

'of information but also of entertainment and services. Two areas in which, without a doubt, the audiovisual format can develop fully' (Masip, 2010).

From the perspective of this new reality in which video and social networks have become major components of newspapers' activity, this article analyses the role of YouTube in Spanish newspapers.

\section{The vital innovation by the press}

Newspapers have witnessed the rapid decline of their two main sources of revenue (advertising and sales) in the wake of the recent financial and economic crisis and the advance of digital development. After several decades, the press is now finally exploiting the Internet's potential, but major questions over the newspaper business model have yet to be answered (López-García; Pereira, 2010; Picard, 2014; Küng, 2015). Publishers today face the challenge of increasing their revenues in a number of ways to enhance their competitive advantage. Through vertical paths, companies have explored opportunities at each link in the classic value chain. In addition to these vertical paths, the press has also explored horizontal paths, moving into the value chains of other industries, and even diagonal paths, moving between distant points in different chains (López-Villanueva, 2011).

This horizontal diversification includes the creation of information products for brands and the production of videos. In both cases, this content could be posted on the newspaper's website or externally. With this type of initiative, newspapers offer a different type of content, but the orientation is the same as that of the original product. In addition to these approaches, newspapers have also diversified their businesses by embracing e-commerce, organising events associated with current affairs and organising events outside the realms of journalism. Newspapers are no longer businesses that sell advertising alongside news; instead, they generate news beyond the confines of their website and offer other sales and services, seeking new commercial margins in the convergent global market.

In short, innovation is a crucial component of the search for new sources of revenue to ensure survival. However, it is not just a question of innovating for its own sake or posting videos on YouTube or the newspaper website. According to Gershon, for innovation to be successful, it must meet certain conditions:

'First, the innovation is based on a novel principle that challenges management orthodoxy. Second, the innovation is systemic; that is, it involves a range of processes and methods. Third, the innovation is part of an ongoing commitment to develop new and enhanced products and services' Gershon (2014, p. 203).

Innovation in journalism has been studied from different perspectives. These perspectives are closely interrelated and difficult to consider in isolation. Examples include:

- business models, ways of monetising content and financing strategies (Carvajal; García-Avilés; González, 2012; Campos-Freire, 2015; Grubenmann, 2016);

- the culture of journalism start-ups (Küng, 2015; Carlson; Usher, 2016; Valero-Pastor; González-Alba, 2018);

- technological issues (Curran, 2010; García-Avilés; Carvajal-Prieto; Arias-Robles, 2018; Anguí-Sánchez; Cabezuelo-Lorenzo; Sotelo-González, 2019);

- changes in production processes (Carlson, 2007; Gynnild, 2014);

- the distribution and marketing of products (Aguado; Martínez-Martínez, 2008); and

- consumption and readership (Hujanen; Pietikainen, 2004; Domingo et al., 2008).

The production of audiovisual content by the press is related to these areas. Studies in this field (Bock, 2012, 2015; Mitchell; Holcomb; Vogt, 2014; Kalogeropoulos; Cherubini; Newman, 2016; Kalogeropoulos; Nielsen, 2017; Mayoral-Sánchez; Abejón-Mendoza; Morata-Santos, 2016; Ortells-Badenes, 2016, Kalogeropoulos, 2017; Hallgren; Nylund, 2018) have shown that the use of videos by the press has grown as technological advances have made it cheaper to create audiovisual material, file sizes have become smaller and download speeds have increased. 
There are many reasons why a medium based on textual information and reflection uses videos as a complementary or central news tool. Kalogeropoulos and Nielsen (2017) affirm that editorial considerations seem minimal and that greater importance is attached to meeting the demands of the readership, complying with the priorities established by Facebook and Google/YouTube for the positioning of information, and seeking a more lucrative approach to advertising. Newspapers often report that news stories accompanied by videos are among the most viewed news items (García-Gómez, 2015, p. 436; Morera-Hernández, 2017, p. 131). Like the other reports in the newspaper, these videos are seen not only in the pages of the newspaper but also outside the newspaper. Similarly, the managing director of Media Hotline has affirmed that

'videos that refer to breaking news or highly topical issues generate more traffic than other types of content' (García-Murga, 2017, p. 145),

which increases distribution platforms' interest in this format.

In addition to the lucrative nature of videos as an online news format that captures readers' attention, online video advertising is often perceived as less intrusive (IAB Spain, 2018). Thus, videos are especially attractive for advertisers and, by extension, for the press. In the European Union, online video advertising is still worth just $10 \%$ of television advertising revenue, but it is growing fast (Fontaine; Grece; Jiménez-Pumares, 2018).

Together, these factors make the success of online videos seem unstoppable and mean that newspapers increasingly use videos. It is estimated that around 82\% of all Internet Protocol (IP) traffic in 2022 will be in this format (Cisco, 2019). In Spain, 95\% of Internet users between the ages of 16 and 65 years watch videos online, and, according to IAB Spain's Online video study 2018 (Estudio anual de vídeo online 2018), news and information represent their fifth favourite type of content.

\section{The role of YouTube as a social network leader}

Digital convergence has led to the integration of text, image, sound and video. Consequently, it is increasingly common for videos to complement written news, and the power of images can be unleashed to enhance the level of spectacularisation. YouTube clearly seems to be the platform of choice for this integration, given the collaborative spirit with which it was created. Today, YouTube is the world's largest and most popular video-sharing community of users. It is the second biggest search engine by number of searchers (after Google). People watch one billion hours of YouTube videos a day, and 400 hours of video are uploaded to YouTube every minute (Smith, 2019). Its profitability and revenue are unclear, and the business could be described as opaque. Not in vain, YouTube, like other multinational giants, has endeavoured to create barriers between content producers and consumers (Whittaker, 2019).

Music, followed by comedy, is the most watched genre of YouTube videos. However, in the last few years, YouTube has also become an essential social network for news distribution. Studies of YouTube from a journalism perspective have focused particularly on the phenomenon of citizen journalism as an alternative form of reporting. YouTube has become a key platform in that it provides reports, through images and sound, of major news stories that journalists are not always able to cover. In addition, YouTube enables content uploading in real time through live streaming. This service, which provides huge value through instantaneous reporting, was launched in 2011.

In reference to the type of news viewed on YouTube, some scholars (Peer; Ksiazek, 2011, p. 56) have noted that viewers seem to prefer non-formal content (a collaborative journalism style) in the digital news environment to videos that follow traditional production practices. Peer and Ksiazek (2011) examined the most popular types of news videos hosted on YouTube. They found that most followed traditional audiovisual information production practices but often defied traditional standards in terms of sources and impartiality. YouTube news is a collective creation, and the forms of news are polarised. The exchange of information and videos on YouTube was studied by Sumiala and Tikka (2015), who stressed that the ritual of objective news is being challenged by YouTube, largely through emerging forms of non-professional news and their rituals of subjectivity.

YouTube is becoming a source of information, and the media are increasingly developing their own YouTube channels. Collaboration with this platform offers a way of tackling the major problem faced by traditional journalism institutions. Peer and Ksiazek (2010, p. 47) and Kalogeropoulos (2017) have alluded to this problem by explaining that the media are aware that most news videos are not viewed on their websites but rather on social networks. According to the Reuters Institute report in 2018, 51\% of news videos are viewed outside the news media, and Facebook accounts for $33 \%$ of views, with YouTube accounting for 25\% (Newman et al., 2018, p. 28).

Virtually all major newspapers have had their own YouTube ${ }^{1}$ accounts for years, and the collaboration between the press and YouTube is becoming closer. In mid-2018, YouTube launched the Google News Initiative (GNI) programme, allocating 25 million US\$ to fund innovative journalism projects in the world of online videos. In addition to this specific initiative dedicated to video journalism, the Digital News Innovation Fund (DNI Fund) has been used by Google in recent years to finance projects by publishers to improve audiovisual offerings by newspapers and strengthen their YouTube presence. YouTube has also launched YouTube Player, a platform that gives newspaper publishers greater control over the content they publish. 


\section{Video profitability and distribution agreements}

In journalism, new Internet user activity and the business and regulatory problems of convergence face an inescapable reality:

'the emerging value chain shows little sign of generating new revenue' (Álvarez-Monzoncillo, 2011, p. 13).

The so-called wealth of networks described by Benkler (2006) seems to lag behind in the case of the press. There is also cannibalisation between digital and analogue markets, and this business has, metaphorically speaking, gone from dealing in euros to dealing in cents. After several decades, business models have still not stabilised, and they are essentially based on advertising, with subscriptions remaining insufficient in most cases, despite the rise of paywalls in recent years ${ }^{2}$.

Against this backdrop of shrinking revenues, a value chain that has been heavily disrupted by the Internet and the unstoppable process of media convergence, newspapers seek revenue from a range of sources, as explained earlier. One way of achieving this goal is through the production of videos and the use of global distribution platforms such as YouTube, Vimeo and Dailymotion. This process of platformisation is changing the media industry (Evens; Donders, 2018, p. 4). Yet therein lies the problem, as the network market has become heavily concentrated in the hands of powerful monopolies (GAFAM, Google, Amazon, Facebook, Apple y Microsoft) under the logic of the winner takes it all. Online advertising revenues are growing steadily, but this increase is not being transferred proportionally to newspaper companies; instead, the network giants are taking over advertising, with $84 \%$ of global digital advertising spend (excluding the Chinese market) going to Google and Facebook (Financial Times, 2017, citing GroupM).

Content on YouTube has shown an ability to influence purchasing decisions (Dehghani et al., 2016), and brands have expressed an interest in establishing a presence there. Newspapers seek advertising from this alliance, but YouTube does not always make things easy for content creators. For newspapers, there are differences depending on whether they operate directly with YouTube Player or with other players such as JWPlayer or Arc Video Player.

YouTube offers advantages to newspapers that use its player. It prioritises these newspapers in its ad auctions and lets them control advertising formats, load ads on videos and directly handle ad purchasing (Google Spain, 2016). However, in return, these newspapers cannot differentiate the way they manage the advertising for the videos viewed on their website.

Newspapers that use other players have more freedom in how they manage advertising for the videos viewed on their website, but they surrender control of the type of advertising shown in the videos they upload to YouTube. Their relationship is based on a 'blind' agreement, whereby YouTube places advertising based on a large number of automated variables processed through its proprietary algorithm. This advertising depends on the user experience in previous searches, the engagement between users, the newspaper and advertisers, the quality of the videos, reputation, subject matter, and so on. YouTube even decides on saturation levels. In this context, the price of the cost per thousand impressions (CPT) or cost per view (CPV) is hard to predict. This amount is known only after payment.

The choice of a particular model is a technological strategy that results in not only differences in income but also major differences in distribution. If newspapers use the YouTube player, all of their videos are played through this social network, even if they can be viewed on the newspaper's website. Using a different player lets a newspaper ensure that all its videos are viewed exclusively on its website, and only a selection of these videos, which are selected by the newspaper, may be hosted on YouTube.

Regardless of the chosen model, advertiser management, to a greater or lesser degree, is still handled by the Google subsidiary. This situation makes it difficult for newspapers to achieve economies of scale by including ads on YouTube. Newspapers therefore prefer to use their own platforms to distribute their videos. However, they use this social network leader to ensure their videos are distributed by the dominant market operator and to achieve extra revenue in an area where it has captured a large share of the video advertising market. According to a report published at the end of 2018 by the European Audiovisual Observatory of the Council of Europe, YouTube has the biggest share of the advertising market for videos shared online (with 32\%), ahead of Facebook (Fontaine; Grece; Jiménez-Pumares, 2018).

For there to be some kind of financial remuneration, YouTube requires the account to have more than 1,000 subscribers and more than 4,000 hours of accumulated viewing time, which is the case for virtually all newspapers. From thereon in, determining the revenue per thousand visits (RPT) is more complicated because it varies with the audience, viewing time, published content and demand for the inclusion of advertising.

Besides the difficulties in monetising online content, producing videos is also expensive and requires considerable investment by newspapers. The cost of production varies widely, and low-cost videos stand alongside medium-quality videos (with a production cost of close to 250 euros) and higher quality videos that have longer life cycles and can generate greater revenues. In any case, it is a question of cost-benefit analysis.

From a business perspective, the inclusion of videos in newspapers and their distribution on platforms such as YouTube can lead to challenges that often relate to the resistance to change and the lack of skills of news professionals (Hallgren; 
Nylund, 2018, p. 77). There is a need to improve human resource management and the skills of journalists (Murschetz; Friedrichsen, 2017), as well as the new working environment (García-Santamaría; Barranquero-Carretero, 2015; Álvarez-Monzoncillo; Suárez-Bilbao; De-Haro, 2016), to build a competitive advantage in the new online information ecosystem. Be that as it may, in the coming years, there will be a battle to control the increase of advertising in news video content between the dominant operator (YouTube), specific newspaper channels and new operators that will try to adapt even better to the needs of advertisers and readers (Amazon, Facebook, Instagram, Netflix and Vox in business). Regulations are also envisaged in all countries to prohibit certain unfair competitive practices linked to the use of algorithms.

\section{Aims and method}

The core aim of this study is to understand the strategies developed by newspapers for value creation on YouTube to increase their revenue. To meet this aim, it is important to know the average number of videos posted daily on YouTube, the topics they address, and the quality and style of the videos hosted on the newspapers' YouTube channels. The goal is to explain the repercussions that a newspaper's YouTube presence has on that newspaper's brand image, considering not only the number of subscribers and videos viewed but also the possible role of influencers, famous journalists or popular youtubers as regular contributors on the channel.

The newspapers analysed in this study are La vanguardia, El país, El mundo, El confidencial, El español and Eldiario. es. Three of these Spanish newspapers are representative of the digital journalism shift from print to the Internet, and three are representative of digital native newspapers that have existed for more than five years. According to comScore data (PrNoticias, 2019) when defining the sample, these newspapers are leaders in terms of the number of visits in their respective categories, and each of them has its own YouTube channel.

The research aims were addressed by conducting a literature review, examining the target of this study and, most importantly, performing content analysis followed by a qualitative adjustment. This method enabled rigorous and systematic analysis of the nature of the videos that the newspapers posted on YouTube. An analysis procedure was then designed with the corresponding variables. To design this procedure, the proposals of other authors (Peer; Ksiazek, 2011; Mayoral-Sánchez; Abejón-Mendoza; Morata-Santos, 2016; Ortells-Badenes, 2016) who have addressed similar themes were considered. The variables and categories were adapted to the specific aims of this study. The initial design was tested with a sample of videos from these six newspapers from one week in March 2019. The results highlighted the complexity of the study and showed the need to simplify some of the variables and redefine certain categories more accurately because the types of videos varied greatly. The final variables focus on technical, stylistic and functional aspects of the videos (see Annex 1).

To design the random sample, the YouTube channels of these newspapers and the videos published in three non-consecutive weeks in March $\left(17^{\text {th }}\right.$ to $\left.23^{\text {rd }}\right)$, April $\left(7^{\text {th }}\right.$ to $\left.13^{\text {th }}\right)$ and May $\left(5^{\text {th }}\right.$ to $\left.11^{\text {th }}\right) 2019$ were chosen. The analysis was not based on selecting the most viewed, most popular or most commented videos because such an approach would distort the study sample. The final sample consisted of 864 videos. Of these,

- 361 were published by El país

- 277 by La vanguardia

- 90 by El mundo

- 56 by El confidencial

- 55 by Eldiario.es and

- 25 by El español.

In the second phase, professionals from the sector were interviewed to help interpret the data from another perspective. The experts' input led to the removal of some of the variables linked to advertising because the coding process might have distorted the results.

\section{Results of the analysis}

The analysis shows that the strategies followed by these newspapers regarding their YouTube profiles and the inclusion of videos on their websites are inconsistent and varied. Different players and different ways of linking to YouTube are used. Some newspapers, namely El país, La vanguardia and Eldiario.es, use Google's own player (YouTube Player), whereas others, namely El mundo, El confidencial and El español, use other players. The choice of player reveals differences in technological strategies, different levels of monetisation and different levels of control over the search for synergies with advertisers.

\subsection{Scheduling by regular contributors on the newspapers' YouTube channels}

El país and La vanguardia upload by far the most content to YouTube. Both newspapers have made a clear commitment to video content. On average, El país uploads 17 videos a day, and La vanguardia 13 . This number is considerably higher 
than the number uploaded by El mundo (four a day), and the digital native newspapers are even further behind in this measure. Despite having been created for the Internet, these newspapers have a small commitment to YouTube content, publishing between one and three videos a day on average. However, the potential to capture revenue does not depend on the number of videos on the channel but rather the degree of professionalisation and reader loyalty. Therefore, it is natural to seek prestigious and well-reputed collaborators in keeping with the editorial line to capture more views.

One of the strategies used to create user loyalty on YouTube channels is to design the scheduling in the form of a linear broadcasting grid. Youtubers also schedule the release of their videos to empathise with their followers. Engagement has its own logic and rules (Chan-Amstel; Wolter, 2018; Dehghani et al., 2016), and there is a certain routine in the way videos are uploaded to suit readers' habits. Video uploading peaks on weekdays rather than weekends, when production is substantially lower. Surprisingly, some digital newspapers do not upload any video content on Sundays.

Table 1. Distribution of weekly video production

\begin{tabular}{|c|c|c|c|c|c|c|c|}
\hline Monday & Tuesday & Wednesday & Thursday & Friday & Saturday & Sunday & Total \\
\hline $18.3 \%$ & $17.9 \%$ & $16.3 \%$ & $19.8 \%$ & $12.3 \%$ & $9.1 \%$ & $6.3 \%$ & N. (864) $100 \%$ \\
\hline
\end{tabular}

In addition, the newspapers create playlists with their main content sorted by topic. Doing so creates consumption routines with respect to collaborators to enhance visibility. Most newspapers showcase videos with well-reputed journalists or figures to differentiate themselves from their rivals. Examples include Iñaki Gabilondo's videoblog in El país from Monday to Thursday and J. M. Gay de Lièbana's video diary, E-Konomía, in La vanguardia from Monday to Friday.

Weekly collaborations are also common. On YouTube, La vanguardia collaborates with Pablo Foncillas, a TED Talk speaker who publishes a youtuber-style ${ }^{3}$ video on Tuesdays, which explains how digital technology influences value creation.

Around $19 \%$ of the videos posted by these six newspapers on YouTube are scheduled periodically. La vanguardia has the most clearly defined and long-term scheduling strategy. It also has the most daily, weekly and fortnightly collaborations scheduled on its channel. Some of these are directly linked to service journalism. Examples are Corpore sano, which deals with health and welfare issues in the style of a consultation, and the fortnightly collaboration with Andrea Vilallonga, an expert in communication and image, who provides advice on how to act in a range of social situations.

El español publishes the fewest videos. However, it also periodically posts offerings such as La cena de los jaleos on Saturdays and El kiosko rosa on Wednesdays. The language used is aimed at younger readers, and these collaborations reflect the newspaper's position as a leader in collaborations related to society news and gossip.

El país has few collaborations that follow a clear schedule $^{4}$. Besides El video blog de Iñaki Gabilondo, which is devoted to political analysis, and El rincón de los inmortales, where historical chess moves are analysed, El país seems to focus on current affairs to offer videos with short-term scheduling that are linked to a range of journalism situations. This strategy is shared by other newspapers. Current affairs undoubtedly influence the contents of newspaper profiles on YouTube. In parallel, newspapers strive to incorporate a scheduling strategy. For example, El confidencial offers weekly summaries of the 'Procés' (in relation to the independence movement in Catalonia), and both $L a$ vanguardia and El mundo report weekly on YouTube on the Supervivientes reality show.

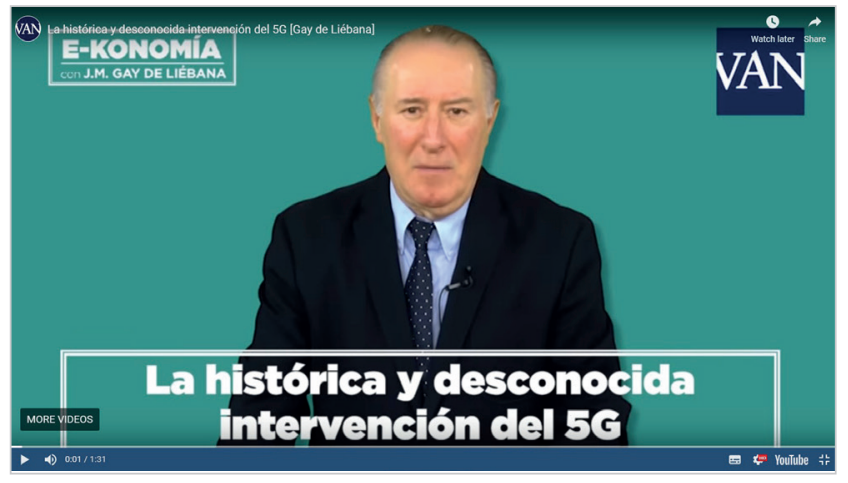

E-Konomía by J. M. Gay de Lièbana

https://www.lavanguardia.com/autores/jose-maria-gay-de-liebana.html

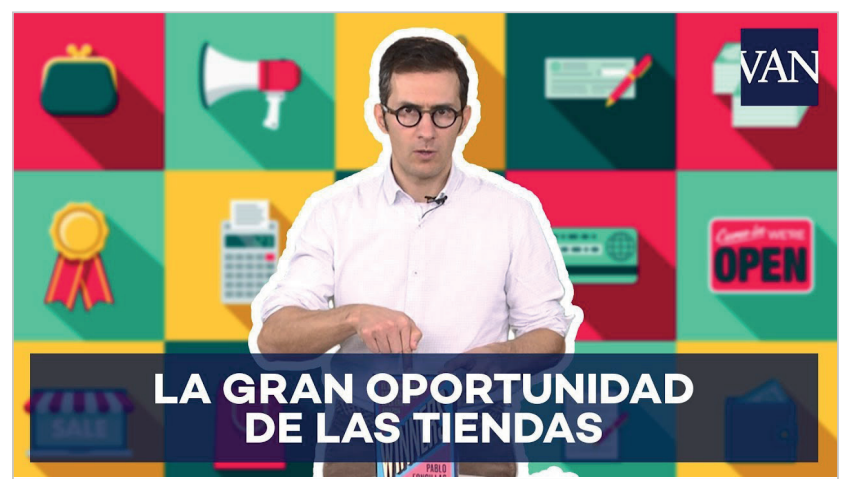

Pablo Foncillas, the anti-guru

https://www.lavanguardia.com/autores/pablo-foncillas.html

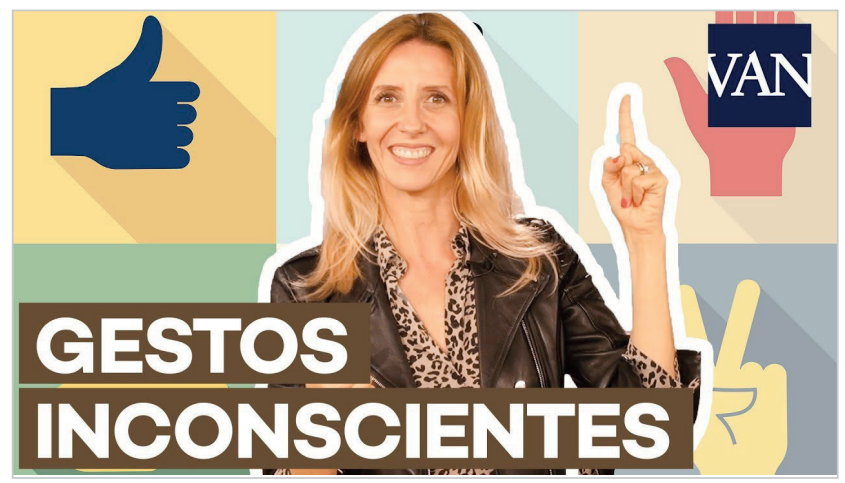

Andrea Vilallonga

https://www.youtube.com/playlist?list=PLhkHcc7EKtBb7ZLGwnmu_QayiA6EUGQS

Image 1. Collaborations in La vanguardia 


\subsection{Technical features of the videos}

The favourable strategy of using social networks to distribute content without investing in the production of that content is followed by the press. User-generated content (UGC) has been used parasitically by companies to generate revenue against the founding principles of the Internet. From an editing perspective, the videos uploaded by Spanish newspapers to YouTube are generally not elaborate. Almost half $(44 \%)$ are live broadcasts generally provided by external sources (mainly institutions such as courts or parliamentary headquarters) or are cuts of these images, agency images or images from other sources such as political parties or national law enforcement authorities or forces that require virtually no editing. Besides the selection of the content, the journalist's work is limited to including tags to identify the type of news or the location of the news event. Although these videos include the newspaper logo, the authorship cannot be said to belong entirely to the newspaper.

A similar percentage of the videos (46\%) are edited in a way that requires greater involvement from journalists, who tend to narrate the news story using captions. The complexity of the editing is inconsistent, but most videos consist of a basic montage. In general, the journalist plays less of a role in these videos than on television, and the use of voice-over by the journalist is practically non-existent, with only $3 \%$ of the videos being narrated this way. The scope of the editing of these videos varies considerably, and the media typically use only images accompanied by music or background sound. The inclusion of statements from key figures in these videos is somewhat limited (24\%), and few videos use complex production techniques or graphic art. The use of immersive virtual content or 360 videos is practically non-existent (0.3\%). Only El país used these techniques during the study period.

Just $10 \%$ of the videos are edited in such a way that the journalist or narrator of the story becomes the main element of the video by telling the story to the camera. In these cases, a talking head appears in about $50 \%$ of the videos, with the other $50 \%$ adopting a more adventurous format, in which the newspapers distance themselves from the traditional language of television. In such cases, the videos also tend to include other types of images that correspond more to the look of a programme or the look adopted by youtubers.

Newspapers seek to squeeze the most out of major news events, whether or not they are their own. This situation sometimes conveys a sense that content is being duplicated. As a general rule, some videos of major events capture the entire event, while other videos offer key statements or moments from that event in instalments.

The perception is that El país and La vanguardia have made the biggest commitment to audiovisual newspaper content on YouTube, not only because they upload the most videos to the social network but also because of the type of editing used on their videos.

The analysis shows that in addition to their variation in quality, the videos hosted by newspapers on YouTube vary considerably in duration. Longer videos can be found alongside medium-length or short videos. However, just under half (45\%) of the videos are between 31 seconds and 2 minutes long. This duration is similar to the news reports aired on the television news. The exception is the digital native newspaper El español, which posts longer videos, with 8 out of 10 of its videos lasting between two and six minutes.

However, this newspaper does not publish what might be called long videos that exceed 30 minutes, something that the other newspapers regularly do on YouTube. Around 15\% of the videos analysed are over one hour long, and 3.3\% last between half an hour and one hour. In all cases, the majority of these videos are live broadcasts, which are not always informative in their entirety.

\subsection{Videos at the service of citizens}

The increase in newspaper content on YouTube has not caused newspapers to abandon their main purpose as sources of information. Just less than $83 \%$ of the videos posted on YouTube are intended to inform viewers. Only a minority are supposed to be for learning or entertainment.

Table 2. Main purpose of the video

\begin{tabular}{|c|c|c|c|}
\hline Information & Learning & Entertainment & Miscellaneous \\
\hline $82.7 \%$ & $3.8 \%$ & $4.3 \%$ & $9.2 \%$ \\
\hline
\end{tabular}

In addition, the style of the videos tends to be formal, which is normally associated with a journalistic style. Only $12.2 \%$ of the videos use the informal look of a home video or the casual style of youtubers.

Home videos are rare. Only $4.1 \%$ of the videos uploaded by the press to YouTube are non-professional videos. El país has the highest percentage of this type of video, with $7.2 \%$ of the videos uploaded to YouTube belonging to the category of home videos edited by the newspaper to increase their information value or improve their appearance. La vanguardia, Eldiario.es and El mundo scarcely use this kind of video. El confidencial and El español did not upload any such videos during the study period. The data suggest that news collaborations between citizens and the digital press on YouTube are minimal. This finding is somewhat surprising given the possibilities for collaboration and the interest of readers in non-formal approaches (Peer; Ksiazek, 2011, p. 56) 
The recurring themes of the videos posted on YouTube by these six Spanish newspapers are national politics (38.4\%), international politics and society (in the same proportion of $14.7 \%)$, culture (7.3\%), sport (4.1\%) and nature (3\%), among others. The difference in approach by each newspaper is also evident. El español devotes by far the most videos to society news and gossip; the rest focus on national political issues.

The uploaded videos do not encourage much involvement from readers. A week after being published, 57\% of videos had still not managed to attract 20 likes, and only $15 \%$ had more than 100 . A separate issue is participation via chat feeds generated by some live shows on YouTube and the support that some newspapers receive from their subscribers.

\subsection{Plays}

In general, the videos that the newspapers post on YouTube are linked to current events. Therefore, their chances of generating a profit from plays are greatly diminished after 48 to 72 hours, although some videos have a longer life cycle. One week after the videos are posted, the average number of plays is low, with $73.8 \%$ of the videos in the sample attracting fewer than 10,000 plays and one in four videos failing to reach 1,000. Competition seems fierce, and most newspaper videos fail to attain high viewing figures, although there are always exceptions.

During the study period, only $1 \%$ of the videos had exceeded 200,000 views one week after being posted (see Annex 2). One of these was a citizen-produced viral video ${ }^{5}$, four corresponded to a live broadcast or newspaper-edited cuts of institutional images, and only two of these videos required a more elaborate editing process and could be considered videos whose authorship belonged solely to the newspaper.

One of these two videos was produced by a journalist at El pais with experience in audiovisual production ${ }^{6}$. The video shows the journalist talking to the camera and explaining how scientists have managed to photograph a black hole for the first time. Although this video is linked to current affairs, its purpose is mainly educational, and it could clearly be used to complement the news story but with a longer life cycle. The other was a live stream of an election debate organised by the newspaper El país along with another subsidiary of the Prisa media group.

Table 3. Percentage of plays within one week of the video's release

\begin{tabular}{|c|c|c|c|c|c|c|c|}
\hline & Elpaís & La vanguardia & Elmundo & El confidencial & Eldiario.es & El español & Total \\
\hline Fewer than 1,000 & 17.8 & 29.2 & 43.3 & 17.8 & 37.1 & 88 & 28.5 \\
\hline 1,001 to 10,000 & 51.8 & 50.5 & 33.3 & 29.6 & 46.3 & 8 & 45.3 \\
\hline 10,001 to 20,000 & 9.6 & 8.7 & 5.5 & 14.3 & 3.8 & 0 & 8.7 \\
\hline 20,001 to 30,000 & 6.1 & 3.7 & 4.4 & 8.9 & 7.4 & 0 & 5.2 \\
\hline 30,001 to 40,000 & 5.7 & 1.4 & 6.7 & 16.1 & 1.9 & 4 & 4.8 \\
\hline 40,001 to 50,000 & 2.5 & 0.4 & 3.3 & 1.8 & 0 & 0 & 1.6 \\
\hline 50,001 to 60,000 & 2 & 1.8 & 1.1 & 3.6 & 0 & 0 & 1.8 \\
\hline 60,001 to 70,000 & 0.6 & 0.4 & 0 & 0 & 0 & 0 & 0.4 \\
\hline 70,001 to 80,000 & 1.4 & 1.1 & 0 & 5.4 & 1.9 & 0 & 1.4 \\
\hline 80,001 to 90,000 & 0.6 & 0.4 & 0 & 3.6 & 0 & 0 & 0.6 \\
\hline 90,001 to 100,000 & 0.3 & 0 & 1.1 & 3.6 & 1.9 & 0 & 0.6 \\
\hline More than 100,000 & 1.7 & 2.5 & 1.1 & 12.5 & 0 & 0 & 2.4 \\
\hline Total & $\begin{array}{c}100 \\
N=353^{*}\end{array}$ & $\begin{array}{c}100 \\
N=277\end{array}$ & $\begin{array}{c}100 \\
N=90\end{array}$ & $\begin{array}{c}100 \\
N=56\end{array}$ & $\begin{array}{c}100 \\
N=55\end{array}$ & $\begin{array}{c}100 \\
N=25\end{array}$ & $\begin{array}{c}100 \\
N=855^{*}\end{array}$ \\
\hline
\end{tabular}

*Nine videos initially uploaded by El país became unavailable after one week.

Viral videos are typically rare, but newspapers are occasionally capable of attracting a high number of plays, thereby generating traffic and revenue quickly, but probably in the short term. Accordingly, some experts affirm that these viral videos are not always useful in the press and fail to create real value for the newspaper (García-Murga, 2017, p. 145).

In addition to the intangible value of a newspaper brand, its economic value must also be evaluated. Approximately one in four videos fails to generate any advertising revenue given that for videos with fewer than 1,000 views, YouTube does not pay for the ad. To avoid ad saturation, videos do not always include advertising, and the number of plays can only offer an estimate of possible revenue. This revenue must be calculated conservatively because ads will not be served in at least $20 \%$ of the videos. In short, this study reveals a high number of low-cost, long-tail videos and few premium videos with the potential for a high number of plays.

Generating a profit from a video whose content is closely aligned with current events is difficult because its short life cycle makes it harder to recover the investment. Accordingly, success in terms of number of plays is greater when the video content is less closely related to current news.

Besides the income earned from the advertising included in their videos, newspapers also resort to brand content, where the use of videos is quite common. In the sample, only the newspapers with print editions have videos that fall into this advertising category. These videos tend to have a higher production cost ${ }^{7}$. 


\section{Discussion and conclusions}

The strategy of incorporating videos in the digital editions of newspapers and distributing these videos on their YouTube channels to increase revenue is highly complex because of certain factors that add little value in enhancing their competitive advantage. A video's success is measured by the number of views and other factors linked to YouTube's proprietary algorithm, although it usually depends on the video's quality, topic or spectacularisation. Seeking a virtuous circle, newspapers encourage readers to participate by commenting and sharing on social networks to increase readership. The search for revenue through video distribution depends on the reputation of collaborators, employee know-how, the brand and the activity of a community of followers that strengthens value creation and the mix of advertising.

All newspapers devise strategies to schedule their videos and build reader loyalty. The most noteworthy model is probably that of La vanguardia, which has the highest number of daily, weekly and fortnightly scheduled collaborations on YouTube.

\begin{abstract}
Some publishers try to capture readers with attractive formats and collaborations with opinion leaders followed by large numbers of followers
\end{abstract}

Some publishers try to capture readers with attractive formats and collaborations with opinion leaders followed by large numbers of followers. Others opt for a more information-centred approach, focusing on educational videos linked to current events with, if possible, a long life cycle that allows for first- and second-time views (e.g. El confidencial). The most common trend is for newspapers to combine these two strategies. Informative videos are placed alongside audiovisual content that is more entertaining or educational than purely informative. In general, different looks and styles are used in the videos uploaded by the press to YouTube. Low-cost videos are posted alongside collaborations with a higher production cost. Every newspaper seeks a differentiating factor that makes it more attractive than its competitors and helps it grow its market share.

The Internet generally demands differential content to attract a high number of plays. In this respect, Spanish newspapers have plenty of room for improvement. One week after being uploaded, $73.8 \%$ of videos had fewer than 10,000 views, and one in four videos had failed to attract 1,000 views on YouTube. In addition, almost half of the content on their channels is low-value content sourced from agencies or institutions. The favourable strategy of using social networks to distribute content without investing in production has been imitated by the press. From an editing viewpoint, the videos that Spanish newspapers upload to YouTube are generally not very sophisticated. Although they include the newspaper's logo, the authorship cannot be said to belong entirely to the newspaper.

Most Spanish newspapers have created a YouTube channel. This alliance with the dominant business in this area gives them a greater chance of visibility, although they often lose control over advertising and the possibility of creating economies of scale with advertisers.
One week after being uploaded, $73.8 \%$ of videos had fewer than 10,000 views, and one in four videos had failed to attract 1,000 views on YouTube

Brand content can be found on the YouTube channels of the analysed newspapers. This approach is mostly used by non-native publications. Advertisers probably place greater trust in the larger print newspapers for their campaigns. This model is particularly lucrative and attractive for newspapers because it gives them access to a steady stream of income that does not normally depend so heavily on the number of plays or algorithms.

The videos produced by the newspapers are intended for their own website, but a second outlet is provided by YouTube. The revenues obtained by newspapers are a small part of their revenue structure, but it allows them to improve their brand positioning with search engines.

The situation of the sampled newspapers varies considerably. Some have exclusive agreements and others have 'blind' contracts. The CPT (cost per thousand impressions) is usually low and ranges from 1 to 4 euros in the Spanish press. Newspapers rely on low-cost videos and struggle to differentiate themselves from the competition, especially through their news content. It seems that further investment in producing better quality videos and enhancing original content is essential if newspapers wish to improve their relationships with YouTube, their readers and their advertisers.

In the coming years, the converging market will grow because young readers increasingly prefer videos to written text. It is essential for newspapers, which have seen their revenues shrink at an alarming rate, to seek greater engagement with their readers. To do so, they must improve their video production and distribution strategies as a key form of innovation to survive in the digital ecosystem dominated by the tech giants.
The profitability of the press on YouTube is for the moment scarce and unequal: private agreements with large headers coexist with other "blind" agreements where profitability will be largely determined by the algorithm 


\section{Notes}

1. The Guardian, Le Monde, Le Figaro, Süddeutsche Zeitung, The Washington Post and The New York Times created their YouTube accounts in 2006. These newspapers were followed by La vanguardia, Die Welt and Corriere della Sera in 2007 and El país in 2008, among many others.

2. Two thirds of the newspapers in the United States and Europe used paywalls in 2017 (Simon; Graves, 2019).

3. Youtubers use colloquial language and inclusive styles to attract viewers. Spoken narration is also mixed with other forms of expression such as graphics, sound, text and performance (Ardèvol; Márquez, 2018).

4. Some of their regular collaborations do not follow a specific release schedule.

5. Viral content is online content that spreads extensively and rapidly as users share it, particularly through social networks.

6. Bruno Martin, head of the Darwin, te necesito audiovisual series at El pais, uses an informal look and youtuber-style approach to address scientific topics to separate the facts from the myths.

7. Las giardinetto sessions in La vanguardia and Mujeres inspiradoras by Accenture in El mundo are notable examples from the study period.

\section{References}

Aguado, Juan-Miguel; Martínez-Martínez, Inmaculada J. (2008). "La comunicación móvil en el ecosistema informativo: de las alertas SMS al mobile 2.0". Trípodos, n. 23, pp. 107-118.

https://www.raco.cat/index.php/Tripodos/article/view/118915/154119

Álvarez-Monzoncillo, José-María (2011). Watching the Internet: the future of TV? Lisbon: Media XXI. ISBN: 9898143835

Álvarez-Monzoncillo, José-María; Suárez-Bilbao, Fernando; De-Haro, Guillermo (2016). "Challenges and considerations of the new labor market in the media industry". El profesional de la información, v. 25, n. 2, pp. 262-271.

https://doi.org/10.3145/epi.2016.mar.13

Anguí-Sánchez, David; Cabezuelo-Lorenzo, Francisco; Sotelo-González, Joaquín (2019). "Innovación tecnológica y social en los nuevos medios digitales norteamericanos. Análisis del caso de Quartz News". Revista latina de comunicación social, pp. 1697-1713.

https://doi.org/10.4185/RLCS-2019-1405

Ardèvol, Elisenda; Márquez, Israel (2017). "El youtuber como celebridad mediática: entre la autenticidad y el mercado". Rizoma, v. 5, n. 2, pp. 72-87.

https://online.unisc.br/seer/index.php/rizoma/article/view/11288

https://doi.org/10.17058/rzm.v5i2.11288

Benkler, Yochai (2006). The wealth of networks: How social production transforms markets and freedom. New Haven: Yale University Press. ISBN: 9780300110562

http://www.benkler.org/Benkler_Wealth_Of_Networks.pdf

Bock, Mary A. (2012). "Newspaper journalism and video: Motion, sound, and new narratives". New media \& society, v. 14, n. 4, pp. 600-616.

https://doi.org/10.1177/1461444811421650

Bock, Mary A. (2015). "Showing versus telling: Comparing online video from newspaper and television websites". Journalism, v. 17, n. 4, pp. 493-510.

https://doi.org/10.1177/14648884914568076

Campos-Freire, Francisco (2015). "Adaptación de los medios tradicionales a la innovación de los metamedios". El profesional de la información, v. 24, n. 4, pp. 441-450.

https://doi.org/10.3145/epi.2015.jul.11

Campos-Freire, Francisco; Rúas-Araújo, José; López-García, Xosé; Martínez-Fernández, Valentín-Alejandro (2016). "Impacto de las redes sociales en el periodismo". El profesional de la información, v. 25, n. 3, pp. 449-457. https://doi.org/10.3145/epi.2016.may.15

Carlson, Matt (2007). "Order versus access: News search engines and the challenge to traditional journalistic roles". Media culture \& society, v. 29, n 6, pp. 1014-1030.

https://doi.org/10.1177/0163443707084346

Carlson, Matt; Usher, Nikki (2016). "News startups as agents of innovation". Digital journalism, v. 4, n. 5, pp. 563-81. https://doi.org/10.1080/21670811.2015.1076344 
Carvajal-Prieto, Miguel; García-Avilés, José-Alberto; González, José-Luis (2012). “Crowdfunding and non-profit media. The emergence of new models for public interest journalism". Journalism practice, v. 6, n. 5-6, pp. 638-647. https://doi.org/10.1080/17512786.2012.667267

Casero-Ripollés, Andreu (2012). "Más allá de los diarios: el consumo de noticias de los jóvenes en la era digital”. Comunicar, v. 20, n. 39, pp. 151-158. https://doi.org/10.3916/C39-2012-03-05

Chan-OImsted, Sylvia M.; Wolter, Lisa-Charlotte (2018). "Perceptions and practices of media engagement: A global perspective". International journal on media management, v. 20, n. 1, pp. 1-24. https://doi.org/10.1080/14241277.2017.1402183

Cisco (2019). Cisco visual networking index: Forecast and trends, 2017-2022. https://www.cisco.com/c/en/us/solutions/collateral/service-provider/visual-networking-index-vni/white-paper-c11-741490.pdf

Curran, James (2010). "Technology foretold”. Chapter 1. In: Fenton, Natalie (ed.). New media, old news. Journalism \& democracy in the digital age, pp. 19-34.

https://doi.org/10.4135/9781446280010.n2

Dehghani, Milad; Khorram-Niaki, Mojtaba; Ramezani, Iman; Sali, Rasoul (2016). "Evaluating the influence of YouTube advertising for attraction of young customers". Computers in human behavior, v. 59, pp. 165-172.

https://doi.org/10.1016/j.chb.2016.01.037

Domingo, David; Quandt, Thorsten; Heinonen, Ari; Paulussen, Steve; Singer, Jane B.; Vujnovic, Marina (2008). "Participatory journalism practices in the media and beyond. An international comparative study of initiatives in online newspapers". Journalism practice, v. 2, n. 3, pp. 326-342.

https://doi.org/10.1080/17512780802281065

Evens, Tom; Donders, Karen (2018). Platform power and policy in transforming television markets. New York: Palgrave Macmillan. ISBN: 9783319742465

Financial Times (2017). "Google and Facebook dominance forecast to rise”. Financial Times, December 4. https://www.ft.com/content/cf362186-d840-11e7-a039-c64b1c09b482

Fontaine, Gilles; Grece, Christian; Jiménez-Pumares, Marta (2018). Online video sharing: Offerings, audiences, economic aspects. European Audiovisual Observatory (Council of Europe), Strasbourg.

https://rm.coe.int/online-video-sharing/16808b2e16

García-Avilés, José-Alberto; Carvajal-Prieto, Miguel; Arias-Robles, Félix (2018). “Implantación de la innovación en los cibermedios españoles: análisis de las percepciones de los periodistas". Revista latina de comunicación social, n. 73, pp. 369-384.

https://doi.org/10.4185/RLCS-2018-1260

García-Gómez, Álvaro (2015). Análisis de la imagen digital y multimedia en la primera página de la prensa online. Estudio comparativo entre España y Alemania. Tesis doctoral. Universidad de Málaga.

https://riuma.uma.es/xmlui/bitstream/handle/10630/12769/TD_GARCIA_GOMEZ_Alvaro.pdf

García-Murga, Yolanda (2017). “Efervescencia heurística en el mundo de la prensa”. En: AEDE (ed.). El libro blanco de la prensa 2016, pp. 136-152. Madrid: AEDE. ISBN: 1696683X2016

García-Santamaría, José-Vicente; Barranquero-Carretero, Alejandro (2014). "La formación universitaria en periodismo. ¿Mera capacitación tecnológica o una formación integral en el nuevo ecosistema informativo?”. Historia y comunicación social, v. 19. pp. 641-651.

https://doi.org/10.5209/rev_HICS.2014.v19.44991

Gershon, Richard (2017). "Digital media, electronic commerce, and business model innovation”. In: Liu, Yu-li; Picard, Robert G. (eds). Policy and marketing strategies for digital media, pp. 203-217. ISBN: 9780415747714

Google España (2016). “Digital news initiative: YouTube player para editores de prensa”. Google España Blogs, 14 septiembre.

https://espana.googleblog.com/2016/09/digital-news-initiative-youtube-player.htm/?m=1

Gottfried, Jeffrey; Barthel, Michael (2015). "How millennials' political news habits differ from those of Gen Xers and baby boomers". Pew Research Center, June 1.

http://www.pewresearch.org/fact-tank/2015/06/01/political-news-habits-by-generation

Grubenmann, Stephanie (2016). Innovation in and from the newsroom. Factors influencing innovation in legacy media. Tesis doctoral. University of St. Gallen.

https://www1.unisg.ch/www/edis.nsf/SysLkpByldentifier/4462/\$FILE/dis4462.pdf 
Gynnild, Astrid (2014). Journalism innovation leads to innovation journalism: The impact of computational exploration on changing mindsets. Journalism, v. 15, n. 6, pp. 713-730.

https://doi.org/10.1177/1464884913486393

Hallgren, Niclas; Nylund, Mats (2018). “Online videos at newspaper websites: A literature review”. The journal of media innovations, v. 4, n. 2, pp. 71-79.

https://www.journals.uio.no/index.php/TJMI/article/view/2339

Hujanen, Jaana; Pietikäinen, Sari (2004). "Interactive uses of journalism: Crossing between technological potential and young people's news-using practices". New media \& society, v. 6, n. 3, pp. 383- 401.

https://doi.org/10.1177/1461444804042521

IAB Spain (2018). Estudio anual vídeo online 2018. Interactive Advertising Bureau. https://iabspain.es/wp-content/uploads/estudio-video-iab-spain-junio2018_vreducida.pdf

Kalogeropoulos, Antonis (2017). "Online news video consumption: A comparison of six countries". Digital journalism, v. 6, n. 5, pp. 651-665. https://doi.org/10.1080/21670811.2017.1320197

Kalogeropoulos, Antonis; Cherubini, Federica; Newman, Nic (2016). The future of online news video. Oxford: Reuters Institute for the Study of Journalism, University of Oxford.

http://www.digitalnewsreport.org/publications/2016/future-online-news-video

Kalogeropoulos, Antonis; Nielsen, Rasmus-Kleis (2017). "Investing in online video news: A cross-national analysis of news organizations' enterprising approach to digital media”. Journalism studies, v. 19, n. 15, pp. 2207-2224.

https://doi.org/10.1080/1461670X.2017.1331709

Küng, Lucy (2015). Innovators in digital news. London and New York: I.B. Tauris \& Co. Ltd.; Reuters Institute for the Study of Journalism. ISBN: 9781784534165

López-García, Xosé; Pereira, Xosé (coords). (2010). Convergencia digital. Reconfiguración de los medios de comunicación en España. Universidad de Santiago de Compostela. ISBN: 9788498873795

López-Villanueva, Javier (2011). “La reconfiguración de la cadena de valor”. En: Álvarez-Monzoncillo, José-María (coord.). La televisión etiquetada: nuevas audiencias, nuevos negocios, pp. 9-31. ISBN: 9788408098706

https://mediaandentertainmentobservatory.files.wordpress.com/2012/04/la_television_etiquetada.pdf

Masip, Pere (2010). "Vídeo en los cibermedios: algunas certezas y muchas dudas". Anuario ThinkEPI, v. 4, pp. 180-185. https://recyt.fecyt.es/index.php/ThinkEPI/article/view/31255

Mayoral-Sánchez, Javier; Abejón-Mendoza, Paloma; Morata-Santos, Montserrat (2016): “El vídeo en la 'prensa' digital española: 2010-2015". Revista latina de comunicación social, n. 71, pp. 775-799.

https://www.redalyc.org/jatsRepo/819/81943468040/index.html

https://doi.org/10.4185/RLCS-2016-1120

Mitchell, Amy; Holcomb, Jesse; Vogt, Nancy (2014). "News video on the Web. A growing, if uncertain, part of news". Pew Research Center's Journalism Project.

http://www.journalism.org/2014/03/26/news-video-on-the-web

Morera-Hernández, Coral (2017). “Lo más leído: infoentretenimiento, propaganda y anécdotas en la versión digital de los diarios españoles". Estudios sobre el mensaje periodístico, v. 23, n. 1, pp. 117-133.

https://doi.org/10.5209/ESMP.55586

Murschetz, Paul; Friedrichsen, Mike (2017). "Does online video save newspapers? An economic performance perspective of adopting online video services in regional news publishing in Germany". In: Friedrichsen, Mike; Kamalipour, Yahya (eds.). Digital transformation in journalism and news media. Media management, media convergence and globalization. Springer International Publishing, pp. 115-128. ISBN: 9783319277851

Newman, Nic; Fletcher, Richard; Kalogeropoulos, Antonis; Levy, David A. L.; Nielsen, Rasmus-Kleis (2018). Reuters Institute. Digital news report 2018.

https://reutersinstitute.politics.ox.ac.uk/sites/default/files/digital-news-report-2018.pdf

Ortells-Badenes, Sara (2016). “Vídeos de producción propia en la prensa digital: buscando el equilibrio entre la calidad y la inmediatez". Revista latina de comunicación social, n. 71.

https://www.redalyc.org/articulo.oa?id=81943468004

https://doi.org/10.4185/RLCS-2017-1081

Peer, Limor; Ksiazek, Thomas B. (2011). "YouTube and challenge to journalism. New standards for news videos online". Journalism studies, v. 12, n. 1, pp. 45-63.

https://doi.org/10.1080/1461670X.2010.511951 
Picard, Robert (2014) “Digital media and the roots of marketing strategy". In: Liu, Yu-li; Picard, Robert G. (eds). Policy and marketing strategies for digital media, pp. 195-201. ISBN: 9780415747714

PRnoticias (2019). "comScore febrero: El País aventaja a El Mundo en millón y medio de usuarios únicos". PRnoticias, 25 marzo.

https://prnoticias.com/prensa/prensa-pr/20172837-comscore-febrero-el-pais-ventaja-sobre-el-mundo

Santín, Marina; Álvarez-Monzoncillo, José-María (2017). “El protagonismo de las redes sociales en la dieta informativa de los millennials". En: Álvarez-Monzoncillo, José-María; De-Haro, Guillermo (eds.). Millennials, la generación emprendedora, pp. 73-105. ISBN: 9788408176060

Sheridan, Lynette; Matthews, Benjamin J. (2017). "Post-industrial journalism as a creative industry". International journal of social, behavioral, educational, economic, business and industrial engineering, v. 11, n. 6, pp. 1575-1583. https://publications.waset.org/10007611/post-industrial-journalism-as-a-creative-industry

Simon, Felix M.; Graves, Lucas (2019). Pay models for online news in the US and Europe: 2019 Update. https://reutersinstitute.politics.ox.ac.uk/our-research/pay-models-online-news-us-and-europe-2019-update

Smith, Kit (2019). "46 estadísticas fascinantes sobre YouTube”. Brandwatch, 29 abril. https://www.brandwatch.com/es/blog/46-estadisticas-youtube

Sumiala, Johanna; Tikka, Minttu (2015). “News rituals of participation: Negotiating temporalities, categories, and hierarchies of news-making on YouTube". Anthropological notebooks, v. 21, n. 3, pp. 5-20.

http://hdl.handle.net/10138/162014

Valero-Pastor, José-María; González-Alba, José-Antonio (2018). “Las startups periodísticas como ejemplos de innovación en el mercado mediático español. Estudio de casos". Revista latina de comunicación social, n. 73, pp. 556-582. https://doi.org/10.4185/RLCS-2018-1269

Webster, James G. (2014). The marketplace of attention. MIT Press. Boston. ISBN: 9780262027861

Whittaker, Jason P. (2019). Tech giants, artificial intelligence, and the future of journalism. New York \& London: Routledge. ISBN: 9781138499973

\section{Annex 1}

\section{Variables used in the analysis}

Video identification

The videos used in the analysis were identified by their title, URL, newspaper and date of publication.

\section{Technical characteristics}

Video editing: A scale ranging from 1 to 6 was used.

1. The lowest level of editing, which corresponded to live feeds provided by another source or clean cuts of images provided by others that either were not edited or were only edited to identify the source.

2. May be sourced from elsewhere, but more sophisticated editing was used. The video was narrated using captions to tell the story and/or background music was added. This category included videos with still images using simple editing that could be performed on a tablet.

3. Montage of images and statements from key figures or editing of various statements from key figures with a clear narrative.

4. In-house editing or talking head. Two levels considered.

5. Videos with elaborate production, graphic art and special programmes or long interviews in which several cameras and elaborate editing were used.

6. $4 \mathrm{~K}$ videos, $360^{\circ}$ videos, immersive techniques, ...

Advertising. An assessment was performed to determine whether advertising was served in the first view of the video and what type of advertising was used: pre-roll, mid roll, post-roll or superimposed banner. An assessment was also performed to decide whether it was a branded video.

\section{Features of style or content}

Duration: Length of video.

Format: The following variables were considered:

Traditional. Three possibilities. 1A. With voice over. 1B. Without voice over but with ambient sound or background music including narration with captions. $1 \mathrm{C}$. Other.

Only voice and image (statements from key figures). Two possibilities. 2A. One. 2B. Several.

Only images with no captions. Two options: 3A. Edited. 3B. Unedited.

Broadcast of a programme or event organised by the newspaper.

Other: ...

Frequency: Whether video was part of a series.

Style: Formal (journalistic or non-journalistic) or informal (amateur/scrappy YouTuber style or other)

Topic: General or specific.

Genre: Information (news, report, interview, ...), opinion.

Function: Informative, educational, entertaining or various.

Core of the video: In-house, agency, institutional feed, other media, other.

Interaction prompted by video

Whether there was chat interaction. Number of views, comments, likes and dislikes one week after upload. 


\section{Annex 2}

Videos from the study sample that exceeded 200,000 plays one week after upload

\begin{tabular}{|c|c|c|c|}
\hline Title & URL & $\begin{array}{l}\text { Newspaper } \\
\text { Date uploaded }\end{array}$ & Origin \\
\hline $\begin{array}{l}\text { Debate de El país con los candidatos a la alcaldía de } \\
\text { Madrid [Debate in El país with the candidates for mayor of } \\
\text { Madrid] }\end{array}$ & https://www.youtube.com/watch?v=sOaDcLU9sdU & $\begin{array}{l}\text { El país } \\
6 \text { May } 2019\end{array}$ & Own event \\
\hline $\begin{array}{l}\text { La primera imagen jamás tomada de un agujero negro } \\
\text { [The first ever image of a black hole] }\end{array}$ & https://www.youtube.com/watch?v=tfKnjyYmtMl & $\begin{array}{l}\text { El país } \\
10 \text { April } 2019\end{array}$ & $\begin{array}{l}\text { Own } \\
\text { production }\end{array}$ \\
\hline $\begin{array}{l}\text { Cierran un gallinero por "molestar" a un hotel rural | Reac- } \\
\text { ción de Nel Cañedo [Henhouse closed for "bothering" a rural } \\
\text { hotel| Reaction by Nel Cañedo] }\end{array}$ & https://www.youtube.com/watch?v=zCWi-XGyRxo & $\begin{array}{l}\text { El país } \\
7 \text { May } 2019\end{array}$ & Citizen \\
\hline $\begin{array}{l}\text { Durísima bronca del juez Marchena a la abogada de } \\
\text { Cuixart: "Yerra usted en su estrategia defensiva" [Harsh } \\
\text { words from judge Marchena to Cuixart's lawyer: "You're } \\
\text { mistaken in your defence strategy"] }\end{array}$ & https://www.youtube.com/watch?v=9Kw4K4xbc6s & $\begin{array}{l}\text { El confidencial } \\
6 \text { May } 2019\end{array}$ & \multirow{5}{*}{$\begin{array}{l}\text { Institutional } \\
\text { images }\end{array}$} \\
\hline $\begin{array}{l}9 \text { lecciones magistrales de Marchena en el juicio del'pro- } \\
\text { cés' } 99 \text { masterclasses by Marchena in the 'procés' trial] }\end{array}$ & https://www.youtube.com/watch?v=jxZW1whOKbl & $\begin{array}{l}\text { El confidencial } \\
18 \text { March } 2019\end{array}$ & \\
\hline $\begin{array}{l}\text { Un hombre lanza unas octavillas frente al féretro de Rubal- } \\
\text { caba [A man throws a handful of pamphlets at Rubalcaba's } \\
\text { coffin] }\end{array}$ & https://www.youtube.com/watch?v=vYv8mAzHh5I & $\begin{array}{l}\text { La vanguardia } \\
11 \text { May } 2019\end{array}$ & \\
\hline $\begin{array}{l}\text { Directo: Capilla ardiente de Alfredo Pérez Rubalcaba en } \\
\text { el congreso } 10 \text { de mayo [LIVE: Alfredo Pérez Rubalcaba's } \\
\text { funeral ceremony in Congress on } 10 \text { May] }\end{array}$ & https://www.youtube.com/watch?v=TRszEtj5TTw & $\begin{array}{l}\text { El país } \\
10 \text { May } 2019\end{array}$ & \\
\hline $\begin{array}{l}\text { El lío del Guardia Civil en el juicio al procés [Confusion of a } \\
\text { Guardia Civil in the procés trial] }\end{array}$ & https://www.youtube.com/watch?v=iJRgrCwC7DU & $\begin{array}{l}\text { La vanguardia } \\
19 \text { May } 2019\end{array}$ & \\
\hline
\end{tabular}

\section{Inforảrea}

Ayudamos a tu organización en la transformación digital y el gobierno de la información

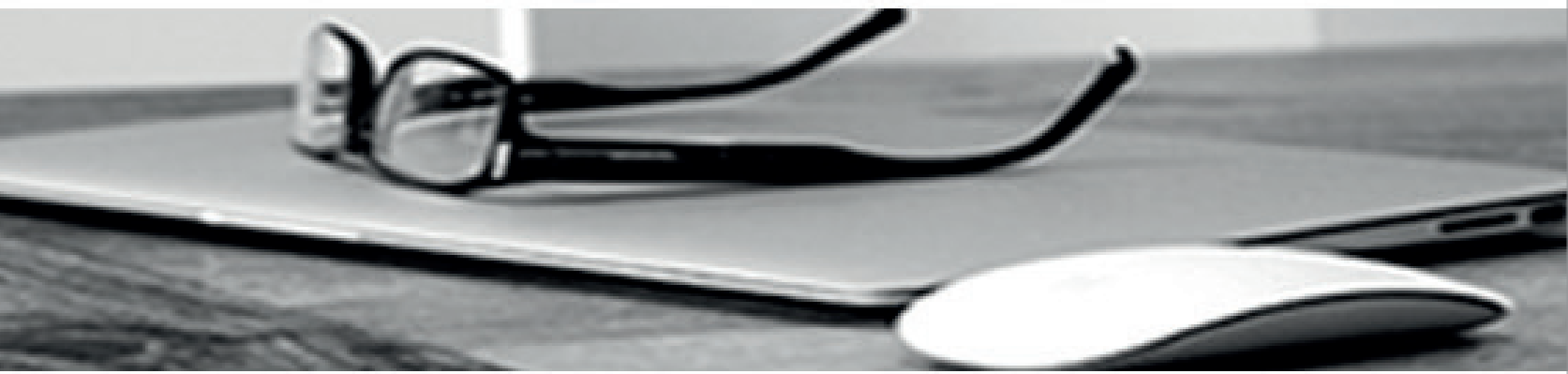

* Consultoría estratégica en gestión y gobierno de la información

* Gestión documental y "records management"

* Gestión de contenidos, intranets corporativas y entornos de colaboración

* Estudios especializados

Clientes satisfechos, cientos de empresas nacionales e internacionales y más de 30 años de experiencia son la mejor garantía de nuestra reputación. 